\title{
Instrumentalizacja prawosławia w polityce wewnętrznej i zagranicznej Rosji w świetle raportu Mirosława Dobrianskiego z 1883 roku
}

Zarys treści: Przedstawiony tekst źródłowy jest memoriałem pokazującym sytuację na terenach pounickich Królestwa Polskiego. Zawiera zalecenia, jakie należy podjąć działania w celu wzmocnienia prawosławia. Zalecono m.in. skoordynowanie działań administracji państwowej, Cerkwi oraz sądownictwa, zakazanie używania polskiego języka w urzędach, nakładanie dotkliwych kar finansowych na księży rzymskokatolickich, wzmocnienie rosyjskiego szkolnictwa oraz wydzielenie omawianego obszaru z Królestwa Polskiego.

Outline of content: The presented source text is a memorial illustrating the situation in the post-Uniate territories of the Kingdom of Poland. It includes the recommendations to be undertaken in order to strengthen the Orthodox Church influence in these lands. It was recommended, for example, to coordinate the actions of the state administration, the Orthodox Church, and the judicature, to ban the use of the Polish language in state offices, impose severe financial penalties on Roman Catholic priests, strengthen Russian education in schools, and separate the district from the Kingdom of Poland.

Słowa kluczowe: Imperium Rosyjskie, Królestwo Polskie, unici, prawosławie, polityka religijna

Keywords: Russian Empire, Kingdom of Poland, Uniates, Orthodox Church, religious policy

W Rosji przez stulecia ściśle splatały się ze sobą kwestie religijne i świeckie. Decydujące znaczenie dla uczynienia z religii prawosławnej instrumentu polityki państwowej miał okres rządów cara Piotra I, który zniósł patriarchat i podporządkował Cerkiew prawosławną władzy świeckiej. Jednak dopiero w wieku XIX, wraz z procesami narodowotwórczymi, władze państwowe uznały, że z religii prawosławnej można uczynić spoiwo Imperium i zaczęły wykorzystywać ją na szerszą 
skalę w celu wzmocnienia państwa. Adresatami tej działalności były zarówno osoby już wyznające prawosławie, jak i te, które zamierzano nawrócić na tę wiarę lub przynajmniej odsunąć od wpływu innych wyznań ${ }^{1}$. O formach i środkach decydowały władze świeckie, realizacją obarczając w sporym zakresie duchownych ${ }^{2}$.

W okresie silnego napięcia na tle religijno-narodowościowym w Rosji funkcję świeckiego zwierzchnika rosyjskiej Cerkwi prawosławnej, tzn. oberprokuratora Najświętszego Synodu, pełnił Konstantin Pobiedonoscew3. Na ten urząd powołał go Aleksander II w 1880 r., ale apogeum wpływów Pobiedonoscew osiągnął rok później, gdy Aleksander II zginął w wyniku zamachu. Oberprokurator odegrał istotną rolę w zaniechaniu przez Aleksandra III działań podjętych przez jego ojca, a mających na celu wprowadzenie przedstawicieli społeczeństwa do centralnych

${ }^{1}$ O roli prawosławia w rosyjskiej ideologii państwowej zob. Z. Opacki, „Bóg zawłaszczony”. Prawosławie $w$ ideologii i polityce państwa rosyjskiego $w$ XIX wieku, w: Naród i religia. Materiały $z$ sesji naukowej, red. T. Stegner, Gdańsk 1994, s. 92-103; I. Smolicz, Istorija russkoj cerkwi 1700-1917, kn. 8, cz. 1, Moskwa 1996; S. Firsow, Russkaja Cerkow nakanunie pieriemien (koniec 1890-ch-1918-e gg.), Moskwa 2002; W. Fiodorow, Russkaja Prawosławnaja Cerkow i gosudarstwo. Sinodalnyj period (1700-1917), Moskwa 2003; A. Zorin, Kormia dwugławogo orła... Litieratura i gosudarstwiennaja idieołogija w Rossii w poslednej trieti XVIII - pierwoj trieti XIX wieka, Moskwa 2004; J. Karrer d'Ankoss (H. Carrère d'Encausse), Jewrazijskaja impierija. Istorija Rossijskoj impierii s 1552 g. do naszich dniej, Moskwa 2007; K. Chojnicka, Narodziny rosyjskiej doktryny państwowej. Zoe Paleolog - między Bizancjum, Rzymem a Moskwą, Kraków 2008; H. Głębocki, Imperium Rosyjskie wobec kwestii narodowych a problem ewolucji rosyjskiej idei narodowej (w epoce wojny krymskiej), w: Polacy i ziemie polskie $w$ dobie wojny krymskiej, red. J. Borejsza, G. Bąbiak, Warszawa 2008, s. 28-62; W. Zajączkowski, Rosja i narody. Ósmy kontynent. Szkic dziejów Eurazji, Warszawa 2009; D. Romanowski, Trzeci Rzym. Rozwój rosyjskiej idei imperialnej, Kraków 2013.

2 O wykorzystywaniu religii prawosławnej przez władze świeckie, aby osiągać cele państwowe, zob. E.C. Thaden, M.H. Haltzel, Russification in the Baltic Provinces and Finland, 1855-1914, Princeton 1981; Th.R. Weeks, Nation and State in Late Imperial Russia. Nationalism and Russification on the Western Frontier, 1863-1914, DeKalb 1996; L. Gorizontow, Paradoksy impierskoj politiki. Polaki w Rossii, russkije w Polsze, Moskwa 1999; A. Kappeler, Rossija - mnogonacionalnaja impierija. Wozniknowienie, istorija, raspad, Moskwa 2000; A. Miller, „Ukrainskij wopros” $w$ politikie włastiej i russkom obszczestwiennom mnienii (wtoraja połowina XIX wieka), Pietierburg 2000; Je. Kempbell (Worobjewa), „Jedinaja i niedielimaja Rossija” i „Inorodczeskij wopros” w impierskoj idieołogii samodierżawija, w: Prostranstwo własti. Istoriczeskij opyt Rossii i wyzowy sowriemiennosti, red. B. Ananicz, S. Barziłow, Moskwa 2001, s. 204-216; D. Staliūnas, Making Russians. Meaning and Practice of Russification in Lithuania and Belarus after 1863, AmsterdamNew York 2007; M. Dołbiłow, Russkij kraj, czużaja wiera. Etnokonfessionalnaja politika impierii $w$ Litwie i Biełorussii pri Aleksandrie II, Moskwa 2010; P. Wiert (Werth), Prawosławije, inosławije, inowierije. Oczerki po istorii rieligioznogo raznoobrazija Rossijskoj impierii, tłum. N. Miszakowa, M. Dołbiłow, Je. Zujewa et al., Moskwa 2012; R. Dżerasi (Geraci), Okno na Wostok. Impierija, orientalizm, nacija i religija w Rossii, Moskwa 2013.

3 R.F. Byrnes, Pobedonostsev. His Life and Thought, Bloomington-London 1968; A. Połunow, Pod włastju obier-prokurora. Gosudarstwo i cerkow' w epochu Aleksandra III, Moskwa 1996; idem, Konstantin Pietrowicz Pobiedonoscew w obszczestwienno-politiczeskoj i duchownoj żizni Rossii, Moskwa 2010; M. Sempołowicz, Oberprokurator Najświętszego Synodu Konstantin Pobiedonoscew wobec kwestii polskiej w latach 1880-1905, praca doktorska napisana pod kierunkiem prof. dr. hab. Zbigniewa Opackiego, Gdańsk 2010. 
organów władzy. Pobiedonoscew stracił urząd w okresie panowania Mikołaja II na fali zmian 1905 r. $^{4}$

Konstantin Piotrowicz Pobiedonoscew, wnuk popa i syn profesora literatury, absolwent Cesarskiej Szkoły Prawoznawstwa ${ }^{5}$ i wykładowca prawa cywilnego, stał się osobą bardzo wpływową na dworze cesarskim. Aleksander III darzył swego byłego nauczyciela dużym respektem, dzięki czemu Pobiedonoscew cieszył się szczególną pozycją. Nierzadko decydował w sprawach wykraczających poza jego resort, a nawet o obsadzie stanowisk ministerialnych. Stał się głównym ideologiem samodzierżawia. Uważał, że jedynym dobrym ustrojem dla Rosji było samowładztwo i za wszelką cenę należało wspierać prawosławie jako czynnik wzmacniający państwo ${ }^{6}$.

Powyższe poglądy przekładały się na konkretne działania podejmowane przez oberprokuratora Synodu, w tym dotyczące terenów byłej Rzeczypospolitej Obojga Narodów ${ }^{7}$. Pobiedonoscew z uwagą śledził sytuację na terenach Królestwa Polskiego zamieszkałych przez unitów - byłych unitów w ocenie władz państwowych ${ }^{8}$.

${ }^{4}$ Por. M. Sempołowicz, Książę Piotr Swiatopołk-Mirski i jego inicjatywa reform wewnętrznych Rosji jesienia 1904 roku w świetle wspomnień i pamiętników, „Echa Przeszłości” (2006), nr 7, s. 69-91.

5 Por. idem, Zanim zostali elita Rosji. Stuchacze Cesarskiej Szkoły Prawoznawstwa w Petersburgu $w$ świetle dziennika Konstantina Pobiedonoscewa $z$ lat 1842-1844, referat wygłoszony na konferencji „Od żartu do karceru. Studenckie występki i uniwersytecka sprawiedliwość w XIX-wiecznej Europie”, Uniwersytet Gdański 19-20.11.2015 r. Artykuł ukaże się w zbiorze pokonferencyjnym.

${ }^{6}$ Idem, Imperialna Rosja w myśli Konstantina P. Pobiedonoscewa. Idea i jej wplyw na praktyke polityczna, w: Ofiary imperium. Imperia jako ofiary. 44 spojrzenia, red. A. Nowak, Warszawa 2010, s. 368-381.

7 M. Sempołowicz, Uwagi oberprokuratora Najświętszego Synodu Konstantina Pobiedonoscewa do memoriału generała-gubernatora wileńskiego ks. Piotra Swiatopotk-Mirskiego z maja 1904 r., „Przegląd Wschodni” 11 (2008), z. 1 (40), s. 963-981.

${ }^{8}$ Likwidację Kościoła unickiego rozpoczęła Katarzyna II w 1795 r. Ostatecznie na obszarze ziem zabranych (w tzw. guberniach zachodnich) Kościół unicki zlikwidował Mikołaj I w 1839 r. Dzieła dokończył Aleksander II, zaliczając unitów Królestwa Polskiego w 1875 r. do wyznawców prawosławia. W lipcu 1884 r. papież Leon XIII udzielił audiencji delegacji unitów. Złożyli oni prośbę do papieża o wstawiennictwo i pośrednictwo u Aleksandra III w związku z prześladowaniami religijnymi, jakich doświadczają ze strony urzędników. Wywiązała się z tego korespondencja między Watykanem a Petersburgiem. Rosyjski minister spraw zagranicznych Nikołaj Giers w liście do sekretarza stanu Stolicy Apostolskiej Lodovica Jacobiniego napisał: „nie ma unitów w Cesarstwie Rosyjskim, są tylko prawosławni i rzymskokatolicy”, cyt. za: H. Dylągowa, Unia brzeska i unici w Królestwie Polskim, Warszawa 1989, s. 68-69; por. A. Boudou, Stolica Święta a Rosja. Stosunki dyplomatyczne między niemi w XIX stuleciu, t. 2: 1848-1883, Kraków 1930; E. Winter, Papstwo i carizm, Moskwa 1964; Rossija $i$ Watikan w konce XIX - pierwoj trieti XX wieka, red. Je. Tokariewa, A. Judin, Moskwa 2003; Z. Opacki, Likwidacja unii kościelnej na „ziemiach zabranych" w 1839 roku, w: Polska - Ukraina. 1000 lat sqsiedztwa, t. 2: Studia z dziejów chrześcijaństwa na pograniczu kulturowym i etnicznym, red. S. Stępień, Przemyśl 1994, s. 119-139; J. Rzońca, Kościót unicki na ziemiach polskich pod zaborem rosyjskim za Mikołaja I i jego likwidacja w 1839 r., w: Kościoly a państwo na pograniczu polsko-litewsko-białoruskim. Źródła i stan badań, red. M. Kietliński, K. Sychowicz, W. Śleszyński, Białystok 2005, s. 142-157; K. Lewalski, Kościół rzymskokatolicki a władze carskie w Królestwie Polskim na przełomie XIX i XX wieku, Gdańsk 2008. 
Ta wielotysięczna grupa ludności chłopskiej formalnie była prawosławna. Spora jej część nie pogodziła się z likwidacją Kościoła unickiego w 1875 r. (tzw. oporni). Korzystali z posług religijnych duchowieństwa rzymskokatolickiego albo w ogóle funkcjonowali poza kościołem instytucjonalnym. Z punktu widzenia władz łamali prawo, ponieważ mieli obowiązki takie jak ogół ludności prawosławnej. Wraz z kształtowaniem się świadomości narodowej chłopstwa coraz większego znaczenia nabierała walka o "rząd dusz"9 nad ludnością wschodnich guberni Królestwa Polskiego ${ }^{10}$.

Pobiedonoscew zdawał sobie sprawę z wagi problemu unickiego, zarazem starał się mieć informacje z pierwszej ręki. Wkrótce po objęciu urzędu oberprokuratora Najświętszego Synodu pojechał do Warszawy i Chełma, a w 1883 r. wysłał ze specjalną misją swojego agenta, żeby zapoznał się z sytuacją w terenie. Zadanie to powierzył Mirosławowi Dobrianskiemu ${ }^{11}$, który znał miejscowe stosunki i był godny zaufania. Pobiedonoscew umieścił Dobrianskiego w kancelarii generała-gubernatora warszawskiego Iosifa Hurki. Oficjalnie misja odbywała się na mocy polecenia Ministerstwa Spraw Wewnętrznych z 30 maja 1883 r. $^{12}$

Dobrianski otrzymał od Pobiedonoscewa ustną instrukcję. Miał zbadać, co przeszkadzało w umocnieniu prawosławia w guberni siedleckiej i lubelskiej oraz określić, jakie były potrzeby religijne chłopstwa w związku z trudnościami w zakresie

9 Była to walka zarazem o rząd dusz i narodowość. Por. S. Wiech, Walka o dusze czy o narodowość? Polityka rosyjska wobec Kościoła greckokatolickiego w Królestwie Polskim w latach 1864-1905, „Nasza Przeszłość” 92 (1999), s. 267-309.

${ }^{10}$ Jednym z pomysłów na ograniczenie wpływu Polaków na miejscową ludność była idea wydzielenia z terenu Królestwa Polskiego części guberni siedleckiej i lubelskiej i wcielenia ich do generał-gubernatorstwa kijowskiego. Istniejące tam regulacje prawne (np. ograniczenia w zakresie szkolnictwa polskiego, zakaz druku gazet po polsku) sprzyjały szybszej rusyfikacji ludności. Pierwsze propozycje padły w 1864 r., wielokrotnie były rozpatrywane na szczeblu rządowym, ale upadały w wyniku rozbieżności zdań między generałami-gubernatorami warszawskimi a władzami centralnymi. Gubernia chełmska powstała w 1913 r. na mocy ustawy uchwalonej przez Dumę w 1912 r. Zob. P.P. Wieczorkiewicz, Z genezy projektu wydzielenia Chetmszczyzny, „Rocznik Lubelski” 23/24 (1981/1982), s. 111-126; A. Wrzyszcz, Gubernia chetmska. Zarys ustrojowy, Lublin 1997; A. Szabaciuk, „Rosyjski Ulster”. Kwestia chelmska w polityce imperialnej Rosji w latach 1863-1915, Lublin 2013.

${ }^{11}$ Mirosław Dobrianski był synem Adolfa - Rusina z Galicji, działacza moskalofilskiego. Pobiedonoscew wspierał A. Dobrianskiego finansowo, wykorzystując w tym celu pośrednictwo duchownego z cerkwi przy ambasadzie w Wiedniu. Dobrianski należał do grupy 11 osób oskarżonych o zdradę stanu w związku z przeciąganiem na prawosławie poddanych cesarza Austro-Węgier. Proces odbywał się we Lwowie w latach 1882-1883. Bezpośrednią przyczynę stanowiło przejście na prawosławie całej gminy unickiej Hniliczki, w której parochem był Iwan Naumowicz, ceniony przez Pobiedonoscewa działacz prawosławny w Galicji. H. Wereszycki, Pod berłem Habsburgów. Zagadnienia narodowościowe, Kraków 1975, s. 192; A.V. Wendland, Die Russophilen in Galizien. Ukrainische Konservative zwischen Österreich und Russland 1848-1915, Wien 2001, s. 202-211; W. Osadczy, Święta Ruś. Rozwój i oddziaływanie idei prawosławia w Galicji, Lublin 2007, s. 238, 246-255.

12 M. Dobrianski w MSW był urzędnikiem do specjalnych poruczeń w randze sekretarza kolegialnego. Informacje biograficzne zob. A.V. Wendland, op. cit., s. 204, przypis 165. 
jego alfabetyzacji. Dobrianski miał ponadto wpłynąć na pochodzących z Galicji duchownych ${ }^{13}$, którym powierzono opróżnione parafie unickie, aby $\mathrm{z}$ większym zaangażowaniem wypełniali obowiązki duszpasterskie oraz w bardziej przyjazny sposób kształtowali swoje relacje $\mathrm{z}$ duchownymi pochodzenia miejscowego i przybyłymi z głębi Rosji, a także z władzami eparchii ${ }^{14}$.

Mirosław Dobrianski odbył wiele podróży po guberniach siedleckiej i lubelskiej. Wracał z nich do Warszawy, aby wysyłać listy do Pobiedonoscewa oraz składać meldunki generałowi-gubernatorowi Hurce i abpowi Leoncjuszowi.

$\mathrm{W}$ grudniu $1883 \mathrm{r}$. raport był już gotowy ${ }^{15}$. Autor przedstawił w nim obszerny zarys historyczny regionu, skupiając się na okresie popowstaniowym aż do współczesności. Scharakteryzował działalność przedstawicieli władz państwowych, ostatnich biskupów unickich oraz duchowieństwa prawosławnego. Był bardzo krytyczny. Podkreślał wahania wyższej i błędy niższej administracji oraz rozbieżności między administracją i sądownictwem, a także wzajemny antagonizm władz duchownych i świeckich. Wskazywał winy konkretnych osób - dotyczyło to przede wszystkim generałów-gubernatorów.

Skrytykował sposób „przejścia” z unii do prawosławia, ponieważ odbył się gwałtownie, bez stopni pośrednich. Stwierdził, że działalność administracji państwowej spowodowała utratę zaufania ludności. Zwrócił też uwagę na brak współdziałania władz świeckich i duchownych. Opisał położenie niższego duchowieństwa prawosławnego. Nie silił się na wybielanie jego obrazu. Przedstawił „agitację” duchownych katolickich, ziemian oraz polskich urzędników. Osobną część poświęcił szkolnictwu. Opisał sytuację wyznaniową oraz narodowościową poszczególnych powiatów guberni siedleckiej i lubelskiej, zwracając przy tym uwagę na stopień alfabetyzacji. Przytaczał dane statystyczne. Skrytykował nauczycielki ${ }^{16}$.

Do raportu został dołączony niżej publikowany Memoriał (w oryginale zapiska) o środkach dla podniesienia rosyjsko-prawosławnej sprawy w Zabużu ${ }^{17}$, w którym

13 Zob. A. Krochmal, Prawosławne duchowieństwo diecezji chełmsko-warszawskiej pochodzace $z$ Galicji (1875-1905), „Rocznik Historyczno-Archiwalny” 6 (1989); eadem, Działalność prawosławnego duchowieństwa $w$ diecezji chełmsko-warszawskiej w latach (1875-1905), „Roczniki Humanistyczne" (1993), z. 2; eadem, Cerkiew prawosławna wobec Kościoła katolickiego na Chełmszczyźnie i Podlasiu (1875-1905), „Rocznik Przemyski” 28 (1991/1992).

14 Zob. J. Fedoryk, Prawosławne duchowenstwo w Carstvi Pol's'komu w 1875-1905 rokach, Donec'k 2013.

15 Raport (urzędnika do specjalnych poruczeń Mirosława Dobrianskiego dla oberprokuratora Najświętszego Synodu Konstantina Poniedonoscewa), Petersburg, 9 XII 1883 r., Nacionalna biblioteka Ukrajiny (dalej: BNU), f. XIII Sinod, d. 230, k. 28-95.

16 Wykształcenie żon duchownych por. K. Latawiec, Duchowieństwo cerkwi prawosławnych resortu celnego i straży granicznej w Królestwie Polskim w latach 1851-1914, „Res Historica” 37 (2014), s. 199-235.

17 „Zapiska o mierach dla podioma russko-prawosławnogo dieła w Zabuże” mogła powstać później niż Raport, jednak nie później niż w 1886 r., ponieważ w grudniu tego roku została opublikowana w prasie polskiej w zaborach austriackim i pruskim. Warto zauważyć, że tytuł wskazuje, iż autor interes Cerkwi i państwa traktował jako tożsamy. 
Dobrianski wskazał, jakie działania powinni podjąć rząd i społeczeństwo rosyjskie, aby zapobiec polonizacji miejscowej ludności ${ }^{18}$. Memoriał dotyczył wschodnich terenów Królestwa Polskiego, tzw. Zabuża, czyli Podlasia i Chełmszczyzny. Objął wytyczne dla władz świeckich i duchownych.

Część tez sformułowanych w Memoriale nie jest oryginalna (choćby postulat wydzielenia guberni chełmskiej głoszony od lat sześćdziesiątych XIX w.), jednak źródło to z kilku powodów można uznać za wyjątkowe. Powstało „na zamówienie” ówcześnie najbardziej wpływowego polityka na dworze carskim. Zostało oparte na danych pozyskanych m.in. podczas wyjazdów w teren i rozmów z mieszkańcami. Objęło całościowy program rusyfikacji - od środków błahych, po daleko idące, jak utworzenie guberni chełmskiej. Do tego ostatniego doszło w 1913 r., a skutków tego wydarzenia nie poznaliśmy jedynie dlatego, że wybuchła I wojna światowa, która zakończyła rządy carskiej Rosji na tym terenie ${ }^{19}$.

Mirosław Dobrianski za pierwszy i główny warunek „zwycięskiej wojny z koalicją sił polsko-łacińskich" uznał połączenie rosyjskich sił rządowych i społecznych ${ }^{20}$. Polscy urzędnicy w instytucjach zajmujących się sprawami wyznaniowymi powinni być zastąpieni - szczególnie w „prawosławnych” powiatach - Rosjanami. Używanie języka polskiego winno być tam zabronione. Wskazana została konieczność przeniesienia do innych miejsc rosyjskich urzędników, którzy ożenili się z Polkami ${ }^{21}$. Główne zadanie władzy rosyjskiej polegało na tym, aby materialnie i moralnie podnieść chłopstwo, zarówno rosyjskie, jak i polskie, choćby wbrew interesom miejscowej szlachty. Księży prowadzących „agitacyjną działalność” należało oddawać pod nadzór policyjny i karać wysokimi grzywnami. Podobnie wysokie kary finansowe powinny spotykać polskich ziemian i ich służbę. Trzeba było zabezpieczyć prawnie obchodzenie prawosławnych świąt i karać mandatami za publiczne ich naruszenie. Kolportaż modlitewników, broszur i innych wydawnictw z Galicji powinien znaleźć się pod nadzorem i być karany mandatami, a same materiały należało wypierać dostosowanymi do prostego odbiorcy ich rosyjskimi odpowiednikami. Duchowieństwo prawosławne powinno być odciążone od zbędnej biurokracji

18 Data została podana jedynie w zakończenie Raportu, por. Raport (urzędnika do specjalnych poruczeń Mirosława Dobrianskiego dla oberprokuratora Najświętszego Synodu Konstantina Pobiedonoscewa), Petersburg, 9 XII 1883 r., BNU, f. XIII Sinod, d. 230, k. 95; Zapiska o mierach dla podioma russko-prawosławnogo dieła w Zabuże, ibidem, k. 105 ob. Do swego Raportu i Zapiski z 1883 r. nawiązał Dobrianski w 1897 r. w innym swym obszernym memoriale dotyczącym sprawy unickiej - O mieroprijatiach moguszczich dat' „uniatskomu woprosu” błagoprijatnoje dla russkoj narodnosti i prawosławnoj wiery tieczenie, Archiwum Państwowe w Lublinie, zespół Kancelarii Gubernatora Lubelskiego (dalej: KGL), 1897: 3/2 t, k. 192-215.

19 Gubernię chełmską utworzono w 1913 r., a już w 1915 r. w związku ze zbliżającym się frontem świeckie władze administracyjne oraz duchowni prawosławni ewakuowali się w głąb Rosji.

${ }^{20}$ Zdaniem Dobrianskiego taki proces jednoczenia sił zapoczątkował nowy generał-gubernator (Hurko objął urząd w lipcu 1883 r.), kończąc zarazem okres wahań w polityce w Kraju Nadwiślańskim. Podobnie prezentował Hurkę Aleksandrowi III Pobiedonoscew.

${ }^{21}$ Por. M. Rolf, Rządy imperialne w Kraju Nadwiślańskim. Królestwo Polskie i cesarstwo rosyjskie (1864-1915), Warszawa 2016, s. 172. 
i uzyskać prawo udziału w wyborach gminnych, a wakaty w parafiach powinny być obsadzane w drodze konkursu. Należało przygotowywać nauczycieli do pracy z ludem, a ich wynagrodzenie podwyższyć. Szybko i ostrożnie trzeba było wprowadzić, choćby „na próbę”, obowiązek szkolny. Dobrianski powołał się na sukcesy germanizacyjne szkół niemieckich. Na koniec autor postulował, aby wydzielić omawiany teren $\mathrm{z}$ reszty Królestwa Polskiego, przynajmniej w sferze szkolnictwa, administracji, sądownictwa, czyniąc głównym ośrodkiem Chełm ${ }^{22}$. Wchodził $\mathrm{w}$ grę wariant, aby utworzyć osobną gubernię. Z czasem obszar ten należałoby przyłączyć do Kraju Południowo-Zachodniego.

Oberprokurator Najświętszego Synodu, członek Komitetu Ministrów i Rady Państwa Konstantin Pobiedonoscew spośród propozycji zawartych w Memoriale poparł na szczeblu rządowym m.in. pomysł utworzenia odrębnej guberni na terenach pounickich ${ }^{23}$. Wykorzystywał znajomość sytuacji w celu forsowania swojej wizji polityki ${ }^{24}$. Raport znalazł także odbicie w publicystyce oberprokuratora ${ }^{25}$.

Instrumentalne traktowanie prawosławia dla realizacji celów państwowych było powszechne w sferach władzy Imperium Rosyjskiego. Uważano to za słuszne. Jak pokazuje raport, prawosławie miało wpływać na różne dziedziny życia poddanych, m.in. na to, czego się uczą, co czytają, jakim językiem się posługują, jak spędzają czas w określone dni.

Skrytykowani przez Dobrianskiego generał-gubernatorzy, przede wszystkim Piotr Albiedinski, również stali na stanowisku, że prawosławie należy promować i wykorzystywać w interesach państwa rosyjskiego. Oni jednak widzieli problem szerzej i starali się bardziej niuansować politykę ${ }^{26}$.

Faktycznie Kościół wiązał ludność labilną narodowościowo z państwem. Jednak w rosyjskiej praktyce, często mechanicznej, dochodziło do tylu błędów, że wykorzystywanie prawosławia przynosiło nierzadko efekty przeciwne do oczekiwanych ${ }^{27}$.

22 Scenariusz Dobrianskiego został częściowo zrealizowany. Zanim formalnie powstała gubernia chełmska, nowymi regulacjami objęto np. szkolnictwo, A. Wrzyszcz, op. cit., s. 11, 147-151.

${ }^{23}$ Pomysł utworzenia nowej guberni popierany na przestrzeni lat przez Pobiedonoscewa spotykał się ze skutecznym sprzeciwem generał-gubernatorów warszawskich Hurki i Aleksandra Imeretyńskiego.

${ }^{24}$ Tajne dokumenty rzadu rosyjskiego w sprawach polskich, drukowane na polecenie KC PPS: memoryał ks. Imeretyńskiego, protokóły Komitetu Ministrów, nota Kancelaryi Komitetu Ministrów, wyd. 2, Londyn 1898.

${ }^{25}$ K. Pobiedonoscew, Istoriczeskaja zapiska o Chotmskoj Rusi i g. Chotmie, o sud'bach unii w Chotmskom kraje i sowriemiennom położenii w niom uniatskogo woprosa, Sankt-Pietierburg 1897.

${ }^{26}$ L. Jaśkiewicz, Polityka narodowościowa caratu $w$ świetle raportów generałów-gubernatorów wileńskich $z$ początku XX w., „Dzieje Najnowsze” (1998), nr 3; Warszawscy generałowie-gubernatorzy o sytuacji społeczno-politycznej Królestwa Polskiego. Raporty Albiedynskiego i Szuwałowa z lat 1881 i 1896, oprac. S. Wiech, Kielce 2007; S. Wiech, „Dyktatura serca” na zachodnich rubieżach Cesarstwa Rosyjskiego. Dzieje kariery wojskowo-urzędniczej Piotra Albiedyńskiego (1826-1883), Kielce 2010.

27 Ukaz tolerancyjny z 17 (30) kwietnia 1905 r. umożliwił „opornym” unitom (formalnie prawosławnym) przejście na rzymski katolicyzm. Skorzystało z tej możliwości ponad 170 tys. osób, 
Poniższe źródło przytaczam za przechowywanym w Bibliotece Narodowej Ukrainy (BNU) w Kijowie rękopisem w języku rosyjskim ${ }^{28}$. Memoriał został opublikowany w 1886 r. w Poznaniu i we Lwowie ${ }^{29}$. Różnice między rękopisem z BNU a publikacją „Dziennika Poznańskiego” zaznaczyłem w przypisach.

\section{Memoriał o środkach dla podniesienia rosyjsko-prawosławnej sprawy w Zabużu}

Optymiści uważają, że czas sam zabliźni głębokie rany, odniesione w ostatnim dziesięcioleciu przez rosyjską Cerkiew i narodowość, a więc przez rosyjskie państwo w Zabużu. Niestety, dla takiego uspokajającego przekonania nie ma godnych zaufania podstaw.

Przeciwnie, doświadczenie ostatnich lat wskazuje na tak szybki i postępujący upadek sprawy rosyjsko-prawosławnej w tym kraju, że bez podjęcia natychmiastowych i prawdziwych środków za jakieś dziesięć - piętnaście lat, nasze Zabuże, zwłaszcza Podlasie, może ostatecznie i bezpowrotnie się zlatynizować i spolszczyć, tak że na gruncie odwiecznie rosyjskim i prawosławnym zostaną tylko izolowane nasze wyspy pośród obcego Kościoła i narodowości.

Na czym powinny polegać te kroki ze strony rosyjskiego rządu i społeczeństwa?

Odpowiedź na to pytanie jest bardzo trudna, szczególnie dla osób nie kompetentnych, do jakich nie mogę nie zaliczyć i siebie.

Tym nie mniej, ze względu na wagę społeczną tej sprawy, postanowiłem przedstawić do uznania Waszej Ekscelencji niektóre swoje opinie o tym, jako materiał do dalszego opracowania i rozstrzygnięcia naszego "problemu unickiego”.

1) Pierwszym i głównym warunkiem skutecznej walki z koalicją sił polsko-łacińskich jest połączenie rozrzuconych dotąd naszych rządowych i społecznych sił pod jedną wspólną chorągwią. Nią może być tylko ogólny rosyjski sztandar: za wiarę, cara i narodowość, przez co naturalnie należy rozumieć wiarę prawosławną, wszechrosyjskiego cara i rosyjską narodowość.

czyli grupa stanowiąca w 1907 r. blisko 20\% ludności Podlasia. J. Łupiński, Ukaz tolerancyjny cara Mikołaja II z 17/30 kwietnia 1905 roku, „Saeculum Christianum” (2001), nr 8/1, s. 197; B. Korzeniewski, Kwestia wyodrębnienia guberni chełmskiej a problem unicki na Południowym Podlasiu, „Radzyński Rocznik Humanistyczny” 4 (2006), s. 94.

28 Zapiska o mierach dla podioma russko-prawosławnogo dieła w Zabuże, BNU, f. XIII Sinod, d. 230 , k. 96-105 ob.

${ }^{29}$ Memoryał podajacy środki dla podniesienia rosyjsko-prawosławnej sprawy w Zabużu, „Dziennik Poznański” (10-12 XII 1886), nr 282-284, (w numerze 282 opublikowano także list z Warszawy do redakcji, do którego był dołączony memoriał, a w numerze 285 z 14 XII 1886 - komentarz redakcyjny do memoriału); Jeszcze jeden plan rusyfikacji, „Gazeta Narodowa” (Lwów 15 XII 1886; jako przedruk z „Dziennika Poznańskiego”), nr 286. 
Szczęśliwy początek do takiego połączenia sił pod wymienionym sztandarem dał obecny główny naczelnik Kraju Nadwiślańskiego [Iosif Hurko - M.S.], słowa i czyny którego przerwały erę wahań i kompromisów z polonizmem i łacinizmem, charakteryzujących działalność poprzednich generał-gubernatorów kraju, a zwłaszcza zmarłego Albiedinskiego.

2) Polscy urzędnicy w tych instytucjach administracyjnych, do których właściwości należy sprawa przywrócenia Zabuża, powinni być uznani za absolutnie szkodliwych dla utrwalenia w nim rosyjskiej Cerkwi i narodowości, więc należałoby ich poprzenosić w inne miejscowości Kraju Nadwiślańskiego albo carstwa, a w ich miejsce przysłać Rosjan z twardymi przekonaniami narodowymi.

Przeniesieni też powinni zostać i ci rosyjscy urzędnicy, którzy ożenili się z Polkami, podobnie jak się to dzieje w Poznańskiem dla skuteczniejszej germanizacji tej polskiej prowincji.

Szczególne znaczenie należy nadawać wyznaniu i narodowości sędziów gminnych, pisarzy i wójtów, stanowczo nie dopuszczać do wyboru ich spośród Polaków i łacinników w rosyjskich powiatach i gminach, i wyznaczać ich z urzędu.

3) Używanie polskiego języka $w$ urzędach na terenie Zabuża powinno być bezwarunkowo zabronione, oprócz tego należy polecić urzędnikom, aby i poza obrębem urzędowania używali tylko rosyjskiego języka albo jego małorosyjskiego narzecza, a w żadnym razie języka polskiego.

4) Sądom należałoby polecić, aby w duchu sprawy rosyjsko-prawosławnej w Zabużu kierowały się nie tylko formalnymi wymogami prawa, ale i pojęciami wyższej sprawiedliwości całkowicie zbieżnymi w tym kraju z prawidłowo pojmowanymi interesami rosyjskiej Cerkwi, państwa i narodowości.

5) Komisarzom spraw włościańskich i innym władzom administracyjnym, mającym do czynienia $\mathrm{z}$ włościanami, należy polecić, aby pamiętali, że nie włościanie, ale polscy właściciele dóbr tworzą zawsze w kraju żywioł burzący porządek, więc główne zadanie władzy rosyjskiej polega na podniesieniu moralnym i materialnym włościanina nie tylko rosyjskiego, ale i polskiego, choćby to sprzeciwiało się życzeniom i interesom miejscowej szlachty.

6) Należy wprowadzić uważny nadzór nad agitacyjną działalnością księży łacińskich, a w razie naruszenia przez nich obowiązujących praw, wymierzać bez żadnego miłosierdzia wysokie pieniężne kary, które są dotkliwsze dla nich niż skargi do łacińskich biskupów i przenoszenie do innych, zazwyczaj lepszych parafii.

7) System wysokich kar pieniężnych należy praktykować także w przypadku antypaństwowych agitacyjnych działan pośród rosyjskiej ludności polskich właścicieli dóbr z ich ekonomami i dworską czeladzią.

8) Należy zabezpieczyć prawnie, aby ludność przestrzegała świąt prawosławnych, wyznaczając kary pieniężne za ich publiczne naruszenie.

9) Niezbędnie należy wprowadzić nadzór nad kolporterami galicyjskich książek do nabożeństwa, broszur itp., a pieniężnymi karami wytępić w nich doszczętnie chęć zalewania Zabuża jezuickimi produkcjami z Galicji. 
Ale całkowicie będzie je można wyrugować tylko systematycznie szerząc przygotowane dla potrzeb ludności książki, broszury, kalendarze itp. rosyjskiego kierunku i pochodzenia.

10) Należy poprawić sytuację duchowieństwa, uwalniając je od pisania metryk i zbędnej korespondencji, która paraliżuje jego samodzielność i zamienia żywych ludzi w maszyny do pisania.

11) Przydzielanie wakujących parafii powinno następować poprzez konkurs, w celu wysuwania najlepszych kapłanów i obsadzania nimi trudniejszych parafii.

12) Miejscowym kapłanom należałoby dać głos i wpływ na zebraniach wiejskich i wyborach, żeby przez to paraliżować szkodliwe wpływy właścicieli ziemskich i księży.

13) Gdyby przekształcić [prawosławne] chełmskie seminarium duchowne na konwikt dla dzieci duchownych przy chełmskim gimnazjum, $\mathrm{z}$ dodatkowymi zajęciami z przedmiotów cerkiewnych, to z tych gimnazjalistów część dokańczałaby teologiczne wykształcenie w akademii duchownej, przez co uzyskałoby się potrzebną liczbę duchownych $\mathrm{z}$ wyższym wykształceniem; z pozostałych można by wybierać dobrych urzędników dla Zabuża, wskutek czego ustałyby skargi duchowieństwa na beznadziejną sytuację ich dzieci po ukończeniu seminarium z powodu braku parafii dla większości z nich.

14) Nadzór nad szkołą i nauką w niej religii powinien być uznany za obowiązkowe zajecie duchownych, bez odrębnego za to wynagrodzenia i pod bezpośrednią kontrolą dziekanów albo specjalnych inspektorów szkolnych spośród duchowieństwa, $\mathrm{z}$ wynagradzaniem ich $\mathrm{z}$ kwot przeznaczanych teraz na wynagrodzenie dla stróży (po 25 rubli) i nauczycieli religii (po 50 rubli).

15) Do obowiązkowych zajęć duchownych należy zaliczyć katechizację niedzielną z dziećmi i powtórkowe szkoły dla dorosłych do określonego wieku.

16) Nauczycieli należy kształcić $w$ seminariach nauczycielskich w kierunku bliższym ludowi, tak żeby otrzymane wykształcenie nie wyrywało nauczyciela $\mathrm{z}$ wiejskiej społeczności, a odwrotnie, dawało mu w niej poważanie i niezbędny wpływ, [kandydatów] na nauczycieli należy wybierać przede wszystkim z miejscowej warstwy chłopskiej i zapewne mieszczańskiej ${ }^{30}$.

17) Żeby uwolnić szkołę wiejską od specyficznego rodzaju młodych nauczycielek, zajmujących się bardziej kosmetykami i kokietowaniem urzędników niż kształceniem ludu, można by określić minimalny wiek do objęcia tej funkcji, podwyższając jednocześnie cenzus umysłowy nauczycielki, wymogiem, zamiast dopuszczalnych teraz skróconych egzaminów na stanowisko nauczycielki, świadectwa żeńskiego gimnazjum albo Maryjskiej Szkoły Żeńskiej.

${ }^{30} \mathrm{~W}$ Memoriale opublikowanym w „Dzienniku Poznańskim” 11 grudnia 1886 r. punkt 16 brzmi: „Zwrócić należy niezbędną uwagę na przygotowanie żon popich odpowiednio do panującego obecnie ducha pośród wychowanic Maryjskiej żeńskiej szkoły, który w ogóle należałoby ściślej związać z potrzebami żeńskiego wychowania miejscowego duchowieństwa”. 
18) Pensję nauczycieli należy podwyższyć przynajmniej do takiej normy, jak w sąsiedniej guberni grodzieńskiej i zarazem uwolnić nauczyciela od bezpośrednich rozrachunków pieniężnych z chłopami, pobierając podatek szkolny razem z państwowym i wypłacając pensję nauczycielowi bezpośrednio ze Skarbu Państwa ${ }^{31}$.

19) Ale wszystkie wyżej wymienione środki nie mogą mieć tak decydującego znaczenia, jak stopniowe i ostrożne wprowadzenie, chociażby „w rodzaju próby”, zasady nauki obowiązkowej. Dlatego, oczywiście, [należy] koniecznie nieco powiększyć liczbę istniejących szkół ludowych, mniej więcej o 33\% i, jednocześnie ze zobowiązaniem rodziców do posyłania w dzieci w określonym wieku do szkoły, wprowadzić jeszcze surowsze zobowiązanie nauczycieli - i zwłaszcza - duchownych [aby] uczyć je, oczywiście w odpowiednim duchu i kierunku.

Przykłady Poznańskiego, Galicji, Węgier dowodzą potężny wpływ na język, przekonania i uczucia ludności obowiązkowej szkoły, germanizującej Polaków w pierwszej prowincji, polonizującą Rusinów w drugiej i madziaryzująca wszystkich bez wyjątku, w szczególności Słowian, w trzeciej.

Ale te przykłady dowodzą zarazem, że działanie obowiązkowej szkoły zależy od świadomego kierunku nauczycieli i ścisłej kontroli ich nauczania. Przy tym zwraca uwagę i ta okoliczność, że najszybciej wynaradawiają się za pośrednictwem szkoły mieszczanie, najbardziej zacięci u nas w kierunku polsko-łacińskim.

Prawda, że oprócz szkoły działa tam na mieszczan i przykład wpływowych stanów, które lubi naśladować ambitne mieszczaństwo; ale i to byłoby możliwe u nas, $\mathrm{w}$ razie zupełnego oczyszczeniu stanu urzędniczego $\mathrm{z}$ elementów polonizujących.

Oczywiście, i obowiązek szkolny nie może być wprowadzony u nas od razu z całym rygorem. Należałoby na początku zwolnić wielu z różnych - mniej lub bardziej stosownych powodów rodzinnych i innych, ale liczba takich zwolnień zmniejszałaby się w znacznym postępie, jak znowu - dowodzi doświadczenie wyżej wspomnianych sąsiednich prowincji Niemiec i Austro-Węgier.

Tą drogą może być stopniowo zdobyta dla prawosławia i narodowości rosyjskiej, a co za tym idzie i dla naszego państwa, młodzież, tj. przyszłość, podczas gdy w obecnym czasie właśnie ta młodzież topnieje pod naszymi nogami, szybko przetapiając się w formy łacinizmu i polskości.

31 Tu w „Dzienniku Poznańskim” 11 grudnia 1886 r. zamieszczono punkty: „Metodę i treść nauki w szkołach ludowych koniecznie należy zmienić $\mathrm{w}$ takim kierunku, aby jednocześnie $\mathrm{z}$ nauką języka rosyjskiego uczyli się i cerkiewnego języka, a zarazem aby część chrestomatii i w ogólności wybór przykładów przy początkowej nauce języka był czerpany z moralno-cerkiewnej sfery, a nie ze zjawisk życia powszechnego i żeby bajki Kryłowa nie usuwały ze szkoły opowiadań z cerkiewnej i ojczystej historii, objaśnień prawosławnego rytuału, praktycznej nauki o rolnictwie, chowie bydła, pszczelarstwa, medycyny domowej itd.”; „W szkole ludowej szczególną należy zwrócić uwagę na rozwój śpiewu chóralnego cerkiewnego, ludowych pieśni, patriotycznych hymnów itp. Jeśli zaś nauczyciel nie ma głosu, w takim razie należy korzystać $\mathrm{z}$ współudziału w tym względzie sługi cerkiewnego (psałomszczyka). Cerkiewny chór szerzony u dzieci pociągnie najprędzej rodziców do cerkwi i zatrzyma ich w niej”. 
Wszystkie inne środki dla powiększenia liczby uczących się w szkole ludowej będą mieć tylko wpływ połowiczny, z wyjątkiem oczywiście zamiany w nich języka rosyjskiego i kierunku na polski.

To, prawdopodobnie, napełniłoby szkoły uczącymi się, szczególnie na Podlasiu i w „opornych” miejscowościach guberni lubelskiej, ale nie na naszą korzyść.

20) Wreszcie pożądane byłoby stopniowe oddzielanie rosyjskiego Zabuża od innych części Kraju Nadwiślańskiego pod względem cerkiewnym, szkolnym, administracyjnym, sądowym itp. z przeniesieniem centrów tych władz do Chełma i przyłączeniem z czasem do Kraju Południowo-Zachodniego. Przez to przeprowadzona byłaby i w rzeczywistości, i w poglądach polskich patriotów linia graniczna pomiędzy dzielnicą etnograficzną lechickiej i rosyjskiej ludności.

Zadałoby to potężny cios fikcyjnej historycznej Polsce, której dokładnym, choć arcyminiaturowym prototypem i obecnie jest Kongresówka, gdzie polska narodowość panuje i nad częściami Litwy (gubernia suwalska) i Rusi (Zabuże), jak za czasów błogosławionej unii lubelskiej.

Skoncentrowanie całego zarządu Zabużem w jednym centrum dałoby możność uzgodnić działania władz świeckich i duchownych. W razie zaś zaliczenia $\mathrm{z}$ czasem tej projektowanej guberni do składu generał-gubernatorstwa Kraju PołudniowoZachodniego, otworzyłaby się możliwość zamienić w rosyjskim Zabużu kalendarz gregoriański na juliański, przez co byłaby zasadniczo sparaliżowana skuteczna do tej chwili agitacja księży i ich pomocników na korzyść obchodzenia przez Podlasiaków świąt katolickich, i pogardy świąt prawosławnych, których dni zbiegały się wtedy w większości przypadków ${ }^{32}$.

Projektowana zmiana stosunków administracyjnych Rosyjskiego Zabuża na takie, jakie obowiązują $\mathrm{w}$ pozostałych prowincjach Imperium mogłaby być dokonana nie nagle, a stopniowo i przy tym w określonej kolejności.

Najprędzej i najłatwiej można połączyć Podlasie i Chełmszczyznę i oddzielić od pozostałych części Kraju pod względem szkolnym, przyłączając rosyjskie powiaty guberni siedleckiej do chełmskiej, a polskie guberni lubelskiej do Dyrekcji Siedleckiej i ustanawiając w pierwszej posady inspektorów, co nawet jest niezbędne wobec projektowanego powyżej wprowadzenia obowiązku szkolnego w przywróconym Kraju.

Na drugim planie można postawić wydzielenie Rosyjskiego Zabuża w oddzielną gubernię, co wiązać się będzie z pewnymi trudnościami.

Wreszcie, w bardziej oddalonej przyszłości, po usunięciu teraz wedle zdania ministra spraw zagranicznych, dyplomatycznych trudności, można by przyłączyć tę gubernię do Kraju Południowo-Zachodniego.

Mirosław Dobrianskij

32 W Memoriale opublikowanym w „Dzienniku Poznańskim” 11 grudnia 1886 r. tu następuje punkt: „Wprowadzić do tego kraju wszystkie obowiązujące w zachodnich guberniach prawa o rosyjskim władaniu ziemią itd. itd." 


\section{Instrumentalisation of the Orthodox Church in the Internal and Foreign Policy of Russia in the Light of Mirosław Dobrianski's Report of 1883}

\section{Abstract}

In 1875, the Uniate Church was abolished in the Kingdom of Poland, and its followers were formally ascribed to the Orthodox Church. Many of them did not observe the Orthodox rites and obligations, and they used the service of Roman Catholic priests. The situation did not change despite the lapse of time. The secular head of the Orthodox Church, Ober-Procurator of the Most Holy Synod Constantin Pobiedonostsev, ordered a report to be prepared about the situation of the Orthodox Church in the post-Uniate areas based on field observations. Those were made by Mirosław Dobrianski, the son of a Russophile activist in Galicia.

In his report, he made a highly critical evaluation of the situation, without sparing the Russians. He pointed out mistakes of the administration, the lack of consistent regulations of officials and judges, and the antagonism between the Church and state authorities. He emphasised the hostile attitude of the Catholic clergy, landowners, and Polish officials. He concluded that in order to defeat the Roman Catholic Church and Polishness, all Russian efforts and forces should be combined. He recommended, among others, to impose more harsh punishment on Roman Catholic priests, to support the peasantry against the nobility, and develop the Russian educational system. He also proposed a gradual separation of the post-Uniate areas from the power of the Warsaw general-governorate to establish a separate gubernya.

Dobrianski's minor recommendations were not implemented, and after the Edict of Toleration issued in 1905, the former Uniates converted in large numbers to Roman Catholicism. The postulate to establish a separate gubernya gained the official support of Pobiedonostsev. It was implemented in 1912 in the form of the Gubernya of Chełm. It is hard to assess the consequences of this fact for the growth of the Orthodox Church and shaping of the national identity of the Chełm Governorate population, for Russia lost this territory as soon as 1915.

\section{Инструментализация православия во внутренней и внешней политике России в свете доклада Мирослава Добрянского от 1883 года}

\section{Аннотация}

В 1875 г. была упразднена униатская церковь на территории Царства Польского, а ее последователи были формально приписаны к Православной церкви. Многие из них не исполняли обязанностей, возлагаемых на последователей православия и пользовались услугами римско-католических священников. С течением времени эта ситуация ничуть не изменилась. Светский глава православной церкви обер-прокурор Святейшего Синода Константин Победоносцев поручил подготовить доклад о положении православия на бывших униатских территориях, основываясь на наблюдении на местах. Его провел Мирослав Добрянский, сын русофильского деятеля из Галиции.

Автор в своем докладе очень критически оценивал ситуацию, не щадя российскую сторону. Он обратил внимание на ошибки администрации, отсутствие согласованных решений чиновников и судей, а также антагонизм духовных и светских властей. Он подчеркнул вражеское отношение католических священников, помещиков и польских чиновников. Добрянский решил, что для победы над католической церковью и польскостью 
надо объединить все российские силы. В конкретных рекомендациях он, среди прочего, предписывал более болезненно наказывать католических священников, поддерживать крестьян против дворян и развивать российское образование. Он также предложил постепенное выделение бывших униатских территорий из-под власти Варшавского генерал-губернатора до тех пор, пока из них не образуется отдельная губерния.

Более мелких мер, предложенных М. Добрянским, не удалось ввести и после публикации указа о веротерпимости в 1905 г., бывшие униаты массово переходили в католицизм. Требование создать отдельную губернию получило на правительственном уровне поддержку К. Победоносцева. Оно было исполнено в 1912 г., когда была создана Холмская губерния. Сложно оценить последствия этого решения для развития православия и формирования чувства национальной идентичности населения Холмской губернии, так как уже в 1915 г. Россия потеряла власть над этой территорией.

\section{Bibliografia}

\section{Źródła}

Ukraińska Biblioteka Narodowa (Nacionalna biblioteka Ukrajiny), f. XIII Sinod, d. 230

Pobiedonoscew K., Istoriczeskaja zapiska o Chołmskoj Rusi i g. Chotmie, o sud'bach unii $w$ Chołmskom kraje i sowriemiennom położenii $w$ niom uniatskogo woprosa, Sankt-Pietierburg 1897.

Tajne dokumenty rzadu rosyjskiego w sprawach polskich, drukowane na polecenie KC PPS: memoryał ks. Imeretyńskiego, protokóły Komitetu Ministrów, nota Kancelaryi Komitetu Ministrów, wyd. 2, Londyn 1898.

Warszawscy generałowie-gubernatorzy o sytuacji społeczno-politycznej Królestwa Polskiego. Raporty Albiedynskiego i Szuwałowa z lat 1881 i 1896, oprac. S. Wiech, Kielce 2007.

\section{Opracowania}

Boudou A., Stolica Święta a Rosja. Stosunki dyplomatyczne między niemi w XIX stuleciu, t. 2: 1848-1883, Kraków 1930.

Byrnes R.F., Pobedonostsev. His Life and Thought, Bloomington-London 1968.

Chojnicka K., Narodziny rosyjskiej doktryny państwowej. Zoe Paleolog - między Bizancjum, Rzymem a Moskwą, Kraków 2008.

Dołbiłow M., Russkij kraj, czużaja wiera. Etnokonfessionalnaja politika impierii w Litwie i Biełorussii pri Aleksandrie II, Moskwa 2010.

Dylągowa H., Unia brzeska i unici w Królestwie Polskim, Warszawa 1989.

Dżerasi (Geraci) R., Okno na Wostok. Impierija, orientalizm, nacija i religija w Rossii, Moskwa 2013.

Fiodorow W., Russkaja Prawosławnaja Cerkow i gosudarstwo. Sinodalnyj period (1700-1917), Moskwa 2003.

Firsow S., Russkaja Cerkow nakanunie pieriemien (koniec 1890-ch-1918-e gg.), Moskwa 2002.

Głębocki H., Imperium Rosyjskie wobec kwestii narodowych a problem ewolucji rosyjskiej idei narodowej ( $w$ epoce wojny krymskiej), w: Polacy i ziemie polskie $w$ dobie wojny krymskiej, red. J. Borejsza, G. Bąbiak, Warszawa 2008, s. 28-62.

Gorizontow L., Paradoksy impierskoj politiki. Polaki w Rossii, russkije w Polsze, Moskwa 1999. 
Jaśkiewicz L., Polityka narodowościowa caratu w świetle raportów generałów-gubernatorów wileńskich z początku XX w., „Dzieje Najnowsze” 30 (1998), z. 3.

Kappeler A., Rossija - mnogonacionalnaja impierija. Wozniknowienie, istorija, raspad, Moskwa 2000.

Karrer d'Ankoss J. (Carrère d'Encausse H.), Jewrazijskaja impierija. Istorija Rossijskoj impierii s 1552 g. do naszich dniej, Moskwa 2007.

Kempbell (Worobjewa) Je., „Jedinaja i niedielimaja Rossija” $i$ „Inorodczeskij wopros” $w$ impierskoj idieołogii samodierżawija, w: Prostranstwo własti. Istoriczeskij opyt Rossii i wyzowy sowriemiennosti, red. B. Ananicz, S. Barziłow, Moskwa 2001, s. 204-216.

Korzeniewski B., Kwestia wyodrębnienia guberni chełmskiej a problem unicki na Południowym Podlasiu, „Radzyński Rocznik Humanistyczny” 4 (2006).

Krochmal A., Cerkiew prawosławna wobec Kościoła katolickiego na Chełmszczyźnie i Podlasiu (1875-1905), „Rocznik Przemyski” 28 (1991/1992).

Krochmal A., Działalność prawosławnego duchowieństwa $w$ diecezji chełmsko-warszawskiej w latach (1875-1905), „Roczniki Humanistyczne” (1993), z. 2.

Krochmal A., Prawosławne duchowieństwo diecezji chetmsko-warszawskiej pochodzace $z$ Galicji (1875-1905), „Rocznik Historyczno-Archiwalny” 6 (1989).

Latawiec K., Duchowieństwo cerkwi prawosławnych resortu celnego i straży granicznej w Królestwie Polskim w latach 1851-1914, „Res Historica” 37 (2014).

Lewalski K., Kościół rzymskokatolicki a władze carskie w Królestwie Polskim na przełomie XIX i XX wieku, Gdańsk 2008.

Łupiński J., Ukaz tolerancyjny cara Mikołaja II z 17/30 kwietnia 1905 roku, „Saeculum Christianum" (2001), nr 8/1.

Miller A., „Ukrainskij wopros” w politikie włastiej i russkom obszczestwiennom mnienii (wtoraja połowina XIX wieka), Pietierburg 2000.

Opacki Z., „Bóg zawłaszczony”. Prawosławie w ideologii i polityce państwa rosyjskiego $w$ XIX wieku, w: Naród i religia. Materiały z sesji naukowej, red. T. Stegner, Gdańsk 1994, s. 92-103.

Opacki Z., Likwidacja unii kościelnej na „ziemiach zabranych” w 1839 roku, w: Polska - Ukraina. 1000 lat sąsiedztwa, t. 2: Studia $z$ dziejów chrześcijaństwa na pograniczu kulturowym i etnicznym, red. S. Stępień, Przemyśl 1994, s. 119-130.

Osadczy W., Święta Ruś. Rozwój i oddziaływanie idei prawosławia w Galicji, Lublin 2007.

Połunow A., Konstantin Pietrowicz Pobiedonoscew w obszczestwienno-politiczeskoj i duchownoj żizni Rossii, Moskwa 2010.

Połunow A., Pod włastju obier-prokurora. Gosudarstwo i cerkow' w epochu Aleksandra III, Moskwa 1996.

Rolf M., Rządy imperialne w Kraju Nadwiślańskim. Królestwo Polskie i cesarstwo rosyjskie (1864-1915), Warszawa 2016.

Romanowski D., Trzeci Rzym. Rozwój rosyjskiej idei imperialnej, Kraków 2013.

Rossija i Watikan w konce XIX - pierwoj trieti XX wieka, red. Je. Tokariewa, A. Judin, Moskwa 2003.

Rzońca J., Kościół unicki na ziemiach polskich pod zaborem rosyjskim za Mikołaja I i jego likwidacja w 1839 r., w: Kościoły a państwo na pograniczu polsko-litewsko-białoruskim. Źródła i stan badań, red. M. Kietliński, K. Sychowicz, W. Śleszyński, Białystok 2005, s. 142-157.

Sempołowicz M., Imperialna Rosja w myśli Konstantina P. Pobiedonoscewa. Idea i jej wpływ na praktykę polityczną, w: Ofiary imperium. Imperia jako ofiary. 44 spojrzenia, red. A. Nowak, Warszawa 2010, s. 368-381.

Sempołowicz M., Książę Piotr Swiatopołk-Mirski i jego inicjatywa reform wewnętrznych Rosji jesienia 1904 roku w świetle wspomnień i pamiętników, „Echa Przeszłości” (2006), nr 7.

Sempołowicz M., Oberprokurator Najświętszego Synodu Konstantin Pobiedonoscew wobec kwestii polskiej w latach 1880-1905, praca doktorska napisana pod kierunkiem prof. dr. hab. Zbigniewa Opackiego, Gdańsk 2010. 
Sempołowicz M., Uwagi oberprokuratora Najświętszego Synodu Konstantina Pobiedonoscewa do memoriału generała-gubernatora wileńskiego ks. Piotra Swiatopołk-Mirskiego z maja 1904 r., „Przegląd Wschodni” 11 (2008), z. 1 (40).

Sempołowicz M., Zanim zostali elita Rosji. Stuchacze Cesarskiej Szkoły Prawoznawstwa w Petersburgu w świetle dziennika Konstantina Pobiedonoscewa $z$ lat 1842-1844, referat wygłoszony na konferencji „Od żartu do karceru. Studenckie występki i uniwersytecka sprawiedliwość w XIX-wiecznej Europie”, Uniwersytet Gdański 19-20.11.2015 r.

Smolicz I., Istorija russkoj cerkwi 1700-1917, kn. 8, cz. 1, Moskwa 1996.

Staliūnas D., Making Russians. Meaning and Practice of Russification in Lithuania and Belarus after 1863, Amsterdam-New York 2007.

Szabaciuk A., "Rosyjski Ulster”. Kwestia chełmska w polityce imperialnej Rosji w latach 18631915, Lublin 2013.

Thaden E.C., Haltzel M.H., Russification in the Baltic Provinces and Finland, 1855-1914, Princeton 1981.

Weeks Th.R., Nation and State in Late Imperial Russia. Nationalism and Russification on the Western Frontier, 1863-1914, DeKalb 1996.

Wendland A.V., Die Russophilen in Galizien. Ukrainische Konservative zwischen Österreich und Russland 1848-1915, Wien 2001.

Wereszycki H., Pod berłem Habsburgów. Zagadnienia narodowościowe, Kraków 1975.

Wiech S., „Dyktatura serca” na zachodnich rubieżach Cesarstwa Rosyjskiego. Dzieje kariery wojskowo-urzędniczej Piotra Albiedyńskiego (1826-1883), Kielce 2010.

Wiech S., Walka o dusze czy o narodowość? Polityka rosyjska wobec Kościoła greckokatolickiego w Królestwie Polskim w latach 1864-1905, „Nasza Przeszłość” 92 (1999).

Wieczorkiewicz P.P., Z genezy projektu wydzielenia Chełmszczyzny, „Rocznik Lubelski” 23/24 (1981/1982).

Wiert (Werth) P., Prawosławije, inosławije, inowierije. Oczerki po istorii rieligioznogo raznoobrazija Rossijskoj impierii, tłum. N. Miszakowa, M. Dołbiłow, Je. Zujewa et al., Moskwa 2012.

Winter E., Papstwo i carizm, Moskwa 1964.

Wrzyszcz A., Gubernia chetmska. Zarys ustrojowy, Lublin 1997.

Zajączkowski W., Rosja i narody. Ósmy kontynent. Szkic dziejów Eurazji, Warszawa 2009.

Zorin A., Kormia dwugławogo orła... Litieratura i gosudarstwiennaja idieołogija $w$ Rossii w poslednej trieti XVIII - pierwoj trieti XIX wieka, Moskwa 2004.

Michał Sempołowicz, dr nauk humanistycznych, Wyższa Szkoła Administracji i Biznesu im. Eugeniusza Kwiatkowskiego w Gdyni. Zainteresowania naukowe: historia stosunków polsko-rosyjskich w XIX-XX w., historia Gdańska i Wilna w XX w. (dokmse@ug.edu.pl).

Michał Sempolowicz, PhD in Humanities, University of Business and Administration in Gdynia. His scholarly interest focus on the history of Polish-Russian relations in the 19th-20th cc. (dokmse@ug.edu.pl). 